\title{
A History of a Reaction of the Mareko People Against the Italian Invasion and the Five Year Italian Rule-in South Central Ethiopia
}

\author{
Yohannes Tesfsye Getachew* Buruk Woldemichael Jima \\ Department of Histroy and Heriatge Management, Jimma University, Jimma, PO box 378, Ethiopia
}

\begin{abstract}
The prime objective of this paper is to explore a history of reaction made by Mareko people against the Italian invasion and the five year occupation. The paper also uncovers the role played by Mareko and other integrated ethno-linguistic individual patriots who fight against Italian occupation and rule at the then Mareko woreda (district). At the eve of the Fascist Italian aggression Mareko people were lived under Mareko woreda (district) which was under the administrative division of Shawa tekely gezat (division of country). Butajira town was the administrative site of the then Mareko woreda. Like other nation, nationalities, and peoples of Ethiopia, fighting class from Mareko people marched in Maychew and other battles to defend their county from Italian aggression. Even though the final battle at Maychew was unsuccessful, they actively resist Italian rule. To speak frankly the then governor of Dobena Sub- district and his officers peacefully submitted and became a leading collaborator, but the majority of Mareko people resisted for the Italian rule. The resistance was mainly led by Wärèqè Märeyamè, spiritual leader of Mareko people in Mareko land, and qegnazmach Tuji Anjilo outside Mareko land. Subsequently the Italian Fascist officials established military camp at Koshe kebele the center of Dobena subdistrict. This paper presents how and why the Italian divide- rule policy failed in the area under the study.
\end{abstract}

Keywords: aggression, Mareko people, resistance, collaboration, Italian rule.

DOI: $10.7176 / \mathrm{HRL} / 53-01$

Publication date: April $30^{\text {th }} 2021$

\section{Introduction}

The people of Mareko are one of the ethnic groups living in the central highlands of Ethiopia. They live in Mareko woreda (district), which is found between the latitudes of 7:55' $\mathrm{S}$ and 8:04' $\mathrm{N}$ and longitudes of 38:26'W and 38:33'E (Daniel 2016).

Mareko people mainly settled and live in Mareko woreda (district). Their ethnic group consists of 66 clans and hundreds of sub-clans. Among those 66 clans of Mareko, 49 clans have now permanently lived under the administrative division of Mareko district and the rest Mareko clans live in the neighboring Meskan district and also Silte Zone, Lanfaro district (Daniel 2016; Sintayhu 2002; Behareseboch-MekerBet 2004). At present, Mareko district is one of the thirteen districts that makeup of today Gurage zone, within the Southern Nations Nationalities and Peoples Regional State (SNNPRS).

\section{The Participation of Mareko fighters against Italian Aggression at the Battle of Maychew}

The head of Fascist Italy Benito Mussolini justifies his campaign for gathered Italians at Rome by remembering the history of Italians defeated by black African nation in Africa. And tell how much he insisted to revenge their defeat in 1888 at historical battle of Adwa and renew their image healing their scar (Sbacchi 1977). By doing this Fascist ambition to create Italian Orientale through uniting its former colonies Eritrea, and Italian SomaliLand with Ethiopia as a new comer in owning colony aggressively waged war on Ethiopia (Marcus 1994; Saheed, 2007). Using Eritrea as stepping-stone Fascist Italy, it was the colony of Italy since 1890, started attacking the area with the then modern weapon.

The time of the political atmosphere found to be uncomfortable to Ethiopia even Ethiopia was member of League of Nation and singed several conventions concerning how to settle will be disagreement among member nations. However Ethiopia's membership cannot stop fascist Italy's aggression and defend its frontier due to British and France policy of appeasement, in which Ethiopia became escape-goat. Emperor Haile Selassie as sovereign represent of the country tried his best to announce a case for concerned bodies and in to appeal for the League of Nations in Geneva (Haile-Selassie 1936; Marcus 1994; Saheed 2007; Sbacchi 1974). Notwithstanding Fascist Italy continued its attacks and invasion in Northern Ethiopia particularly in Tigray where local war chiefs on defending line, but until the Wal-Wal incident and Adwa attacks the Emperor had not declare state of emergency. On 1, October 1935 the emperor announce state of emergency to which provincial governors and lower administrative rank governors recruit and organize fighters in the side of National army (Haile-Selassie 1936; Marcus 1994; Saheed 2007).

In responding the decree of Emperor Haile Selassie I Mareko People living in Mareko district recruit fighters and organized both man power and logistic supply under the then nobility Qäñazmaće Oshebe Mesebo led in coordinating pre-requests for coming campaign. Mareko recruited fighters were composed of experienced notable fighters most of them veterans of Adowa and fresh fighters. Among the veterans of Adwa, qän̆azmaće 
Oshebe Mesebo, Basha Weld Giyorgis, Basha Gebre, Tessema Kasetew, Fallo Fonnee, Leme Mollorro, Tessema Abba Bora, Basha Weldayes and Gade Lije were leaders of fresh recruits (Edemo 2007; Informants; Abegaz Ambese Tira, Imam Tuke). Mareko fighters organized under Kembata force which led by Ras Getachew Abate governor of Kembata awraja fight Italian invading force in Mekele and Miychew at the last anti-Fascist and anticolonial battle and other several battle fields like Bale and Dolo. (Edemo 2007; Informants; Abegaz Ambese Tira, Imam Tuke)

After unsuccessful battle of Miychew the Emperor exile to England. The news about his exile and the situation of the ongoing war in different battles and its result which brought by veterans from war front make fear on peoples living in Mareko district particularly on Mareko people. However, peoples who live the Province and neighboring localities tried their best to sustain the former peace and maintain the security of the area from the will be anarchy born ethnic conflict, religious conflict and robbery, through traditional dispute solving mechanisms after representatives of different ethnic and linguistic groups made convention (Tesfa 1995); Beside its main agenda, the occasional convention also gave deep emphasis to unity against Fascist Italy. Concerning resistance and coming soon Fascist-Italy rule, representatives of neighboring Mareko people, Meskan-Gurage, Selt'e people, and Sodo-Gurage vote and passed resolution neither submission nor collaboration on the behalf of their people.

Despite such occasional convention, advanced part of Fascist Italy officials found relatively better favorable condition to apply their means and method to effectively control the area and complete submission of Mareko people through religious based intra-ethnic disunity created among the population of Mareko woreda (district). Their divide and rule policy seems to be effective after they got the peaceful submission and collaboration of local Muslim religious leader among Meskan Gurage and neighboring Silte areas who coordinated with the formerly formed local anti government movement called Goggt, which was actively took fame under Imam Sugato Zeyne (Bustorf 2009; Vaughan 2003) to whom several anti Imperial propaganda and readjustment promised and used for Fascist consumption.

Most of collaborators among the population of Mareko woreda welcomed Italians and submitted peacefully since already they were informed that the Italians policy towards Islam was aimed at establishing good relations (Bustorf 2009; Tesfa 1995; Sabachi 1985). Those collaborated local chiefs and religious leaders with their followers ignorantly leave the past peaceful interaction and ethnic integration a side readily for the will be dispute and conflict.

However before Fascist Italy control the area, conflict erupted in western neighbors of Mareko people against Kembata and Mareko fighters which lead by fitawrari Tamrat in a way returning home from national battle fields. In $15^{\text {th }}$ May, 1936 some Sodo-Gurage youths who consider absence of local security chief and the gap created in administrative office where most of them were in these national battle fields and used it as an opportunity to rob these travelers when they passing neighboring Sodo-Gurage area (Edemo 2007; Tesfa 1995).

Due to their attempt of robbery and defensive action made by veterans many were killed both sides. This robbery and ill-treatment made by Sodo-Gurage youths opposed by most of Sodo people, for instance qän̆azmaće Bobe (Tesfa 1995) refused attending the funeral ceremony of his son who died in the course of robbery. This conflict created a serious of bloodshed war among Sodo and Mareko. More or less the above and other ethnic based conflicts and disputes and Fascist propaganda created dilemma on Mareko people.

Generally more or less for the Ethiopian forces which had on the way to back home after unsuccessful war in northern fronts and other fronts, the journey was difficult since in some areas peoples used an opportunity to retaliate the exploitive and oppressive regime by robbing soldiers (Alebachew \& Samuel 2010) who were considered as the guardian of the feudal government. Just like the Sodo-Gurage area, the Mareko among the youths whose hidden resentment motivated and organize to use the condition for their anti regime sentiment by attacking the government fighters who were in journey to back home from battle field. Then in 1936 the anti government Mareko group attacked the Arsi force which was lead by déjàmać Wäldä-Şadiqe (Alebachew \& Samuel 2010).

\section{The establishment of Italian Camp at Butajira, and Koshe town, and the Battle of Goggeti}

The first collaborators in Mareko district promised economic and political privileges by Italian officials following the establishment of their military camp at Butajira, the then administrative center of Mareko district. However they faced strong resistance among mass and socially hated due to their activities being agent of harsh treatment flogging and torture including killing with fire squad and hanging (Tesfa 1995).

The first Italian officials arrived in Dobenna Sub-district (mikitel wäräda) at Koshe qäbälè where Mareko people main land and secure the submission of grazmach Debo Agebo (Sintayhu 2010; Informants; Ato Nune, \& Abegaz Anbese) who was veteran of the battle of Adwa appointed as governor of the sub-district by Imperial government officials. While the balabbats, and, at that time, most of powerful leaders of the Mareko qän̆azmać Oshebe Mesebo, Baša Weld Giyorgis, Baša Gebre, Tessema Kasetew, Fallo Fonnee, Leme Mollorro, Tessema Aba-Bora, Basha Weldayes and Gadde Lije were obliged to go to the different front, gerazmach Debo Agebo 
stayed behind to guard his Sub-district but he exploited the situation for his own sake and quickly improved his military and political position.

This act of collaboration made division among Mareko people based on clan which traced former power rivalry since the time Menelik conquest. The ruling clan opposed by mass under the leadership of Šäbo clan, (Sintayhu 2010; Informants; Ato Nune, \& Abegaz Anbese) rival clan in claiming to recognize as nobility of their respective area. But now can produce several supports from members of other clans and can form anti Fascist Italy resistance group and joined organized resistance movement due to former balabbats collaboration to secure an already taken power.

In addition to clan based both anti-Italian and anti-collaborator organized form of resistance movement, Mareko patriots got support from their spiritual leader named Wärèqè Märeyamè, who strongly and officially displayed anti-Italian rule. Reportedly her role in leading anti-Italian movement known by Italian officials who established their head quarter at Butajira through their collaborator named azmaće Eremora (Edemo 2007; Informants: Ato Nune, \& Abegaz Anbese). Italian officials arrived to confirm the resistance of Wärèqè Märeyamè, but reluctant Werke refused submission. Consequently she accused being a witch and mastermind behind the 1937 attack on Italian military convey when crossing Mareko area at Dida locality during their journey from Ziway to Butajira which resulted death of two Italian military officials. Thus Wärèqè Märeyamè and other captured patriots who were active in the area in fighting the Italians taken exile to Mogadishu. Among those captured Ethiopian patriots in Mareko district Ato Bezabhe Agune member of the artillery division was the most important. Ato Bezabhe Agune was among a few lucky Ethiopian prisoners who got a life chance to back home after the evacuation of Italians in the Horn of Africa. (Informants; Ato Wuletaw)

After the Dida attack, unorganized form of anti Fascist resistance became smooth after several Mareko men's flogged, imprisoned and direct participants of the anti Fascist rule punished death sentence. However, the exile sentence on Wärèqè Märeyamè revived the former passive resistance and the majority Mareko who lost its spiritual leader waits an opportunity to revenge the lost. Even some individuals secretly communicate with the patriots who were in the area (Edemo 2007; Informants Imam Tuke \& Ato Lile)

Fascist Italian Officers side by side applies both peaceful way of owing submission and forcing local notable elders and clan chiefs through warning (Sbacchi 1974). Collaborators among Mareko seems also played a major role in indoctrinating fascist policy to minimize ongoing harsh treatment which used by Fascist officials both on them and their people.

Fascist Italian administration in Mareko land faced both support and resistance which divide population of the area based on ethnic and linguistic division found being inconsistence for their means of owing the submission of Mareko and other linguistic groups. Their containment policy initially seems to be profitable since they can produce collaborators from ethnic and religious group until Mareko people got lesson from what Fascist officials did on peacefully submitted patriots to whom through agents promised mercy and award for surrender but after surrender publicly killed.

Even though qän̆azmać Tuji Anjilo and his followers exiled to remote area to continue his anti Italian occupation before Italian officials advanced Mareko-land and well- come by däjazmać Debo Agebo, the then governor on the behalf Mareko people. Anti -fascist resistance sentiment revived after the news about the army of Ras Desta Damtew approaching in Mareko-land border reached among Mareko people in Mareko waräda. Thus anti-Italian group among Mareko people met to fight Italian force by combining with the force of Ras Desta Damtew which moved from Arbegona (Aregawi NY) where they were in defending line against the invading army in Southern Front with his army reached border area of Mareko land and Sodo-Gurage area.

Ras Desta Damitaw, the governor of Sidamo, son-in-law of the Emperor, appointed to lead the southern Ethiopian force in south had been in a way to retreat after unsuccessful defending against the southern Italian force with his notable war leaders, däjazmać Beyene Maried, the husband of princess Romanwork (Sbacchi 1974) and däjazmać Gebremariam Gari, and with remnants of their soldiers (Marcus 1994; Bharu 2002; Tesfa 1995).

The advancing part of southern Italian infantry under the leadership of General Navarrini met the retreating force of Ras Desta at a place called Goggiti, a border area of Mareko and Sodo-Gurage on 24, February 1937 (Bahru 2002; Tesfa 1995). The coming of national army in the area revive the fighting moral of anti Italy Mareko resistance groups who lost spiritual leader and faced harsh treatment from Italians and collaborated class.

The force of Ras Desta which was attacked by Italian at Goggiti (Bahru 2002; Tesfa 1995; Dinberu et al. 1995) get support from Mareko people particularly from the local area, and fighting continued for three days, until the enemy became under upper handed position. The Goggiti war, in which fresh fighters of Mareko people who were knowledgeable of land scope of the area than Italians engaged in it ended without victory particularly after the death of däjazmać Gebremariam Gari, and däjazmać Beyene wounded (Marcus 1994; Bharu 2002; Tesfa 1995) and soon died, their position was among notables Imperial government in Harer, and the governor of Bale respectively.

Consequently the force of Ras Desta disbanded and Mareko irregular fighters back home to whom fighting Italian force face to face satisfied despite losing the battle. Concerning the final and the decisive events which 
distorted the life of Ras Desta following the battle of Goggiti, Bharu said nothing at all.

Ras Desta who lost the battle and his friends died and wounded went to Butajira area with hope to get antiItalian support and/or place of fugitive. It was not suddenly calculated solution to escape from chasing Italian force to whom he narrowly escaped two times; at Arbegona and at Goggiti rather it was the birth place of his mother where his maternal-side kinsman had been live. However the inverse was true his lost military support where he lost acceptance from local Meskan Gurage who formerly collaborate to Italians under their religious leader, and live as fugitive (Informant: Ato Teshome Mekonnen: Dinberu et al. 1995).

Ras Desta faced strong opposition by the local collaborators when he attempted to hide himself at the strategic place of Mount Zibider. His surrender was also masterminded by local collaborators through fake promise. Officials of Italian administration at Butajira sent their collaborators of the locality to peacefully give up and they found him in local place called Yetebon around Butajira (Dinberu et al. 1995; Tesfa 1995; Informants, Ato Teshome, \& Ato Wuletaw).

Concerning the exact fugitive place of Ras Desta, Aregawi Berhe's mentioning "Eya" is not suited with the exact place (Aregawi Berhe NY). According to informants from the area and the available memo of the contemporary Clergy Tesaf Gebryes Yetebon was not only the exact place of Ras Desata's fugitive but also the birth place of his mother. The granddaughter of Ras Desta named Miheret established and run two semi charity projects called Mercy project. Her project encompasses one hospital and a secondary school for needy community members at her ancestral land, Yetebon near Butajira (Informants, Ato Teshome, and Ato Wuletaw).

Ras Desta who hopelessly surrender killed by shooting squad with his few loyal follower who were remnants of Imperial troops of southern front, at their camp Butajira and his body was secretly taken by Bekele Weya who had conducing patriotic movement in the area basing at Sodo and buried at a place called MedreKebde Abbo Church in Sodo Gurage area (Tesfa 1995; Informant; Ato Teshome, Ato Wuletaw )

The death of Ras Desta Damitew created a very meaningful feeling to Italian in which by doing so they secured the area from probable act of anti-Italy resistance movement. Subsequently in the following month, just after the death of Ras Desta, in March 1937 the Italian forces occupied Hossana. Tenente Aimoni, was the first Italian commissioner at Hossana who appointed and exercise jurisdiction over the people of Mareko, Gurage, Hadiya, Kembata and Tembaro, Soddo-Oromo, and Weliso (Teclehaimanot 2014) under their main camp and resident at Hossana the Italian official's setup camps at each former government administrative towns. Butajira town, the administrative site of Mareko district where they formed temporary camp now after the first commissioner arrived at Hossana becomes the site for assigned Italian officials to rule the district.

Under Commissioner Tenente Aimoni, Commissioner Casamaro was appointed heading the Italian camp at Butajira. Most of the time during his supervision Commissioner Casamaro prefer locally recruited soldiers to Somalis, Eritrean or Italians due to two reasons; first to overcome language barriers and, secondly, to develop his geographical knowledge of the area. He was the most notorious Italian Officer in the area who accused committing war crime and genocide particularly he was responsible for the genocide of 375 civilian churchmen at Medere-Kebed Monastary in the neighboring Soddo-Gurage (Tesfa 1995).

Side by side Italian Officers tried their best to handle the patriotic movement of anti-Italian government peacefully. For instance, in 1938 an Italian General Dolosso arrived at Goggeti the border locality of Mareko. The objective of General Dolosso was to meet on the reconciliation process of the area with the local notables. Nevertheless the patriots ignored him and his first mission was failed. Subsequently in the same year on March 27, General Dolosso accompanied with other General who was Commissioner of Jimma arrived at a place called Kondalditi near Mareko. At Kondalditi the Italian force lead by these two Generals fight against patriots of the area. However the battle ended without victory of both sides (Tesfa 1995).

Due to the effective Italian propaganda in isolating Muslims' of the majority, particularly from the side of Meskan-Gurage, population of Mareko district from resisted group, they started to rule the area through their collaborators under their strict supervision at Butajira. Moreover anti-Italian movement among the Mareko people lost practical movement after the execution of Ras Desta and become passive until Italian officials start to recruit youths among Mareko for corvee during their Zway-Butajira road construction which cross Mareko-land. Generally Italian officials who hopefully relies their trust on collaborators of the area, divide and rule policy, and modern arms to control Ethiopia. Eventually it was true in areas like Mareko district where these three factors secured Italian occupation and temporary colonial administration until 1941. 
Photo, 1

Ras Desta Damtew after he was surrendered to the Italian officials at Butajira.

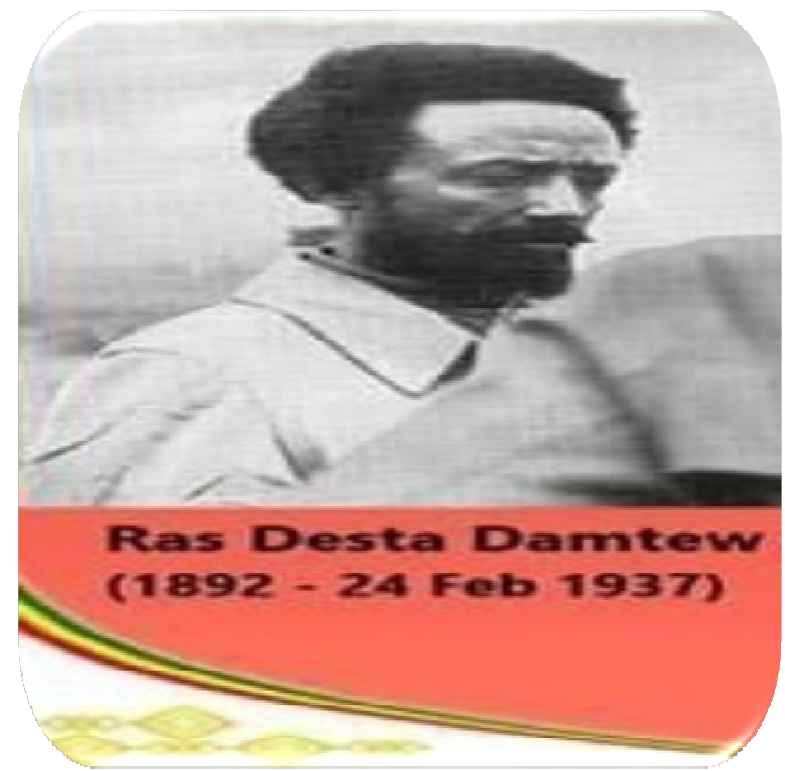

Photo 2. The compound of the present Butajira Behre General Secondary School the former camp of Italian during their occupation where Ras Desta Damtew was killed.

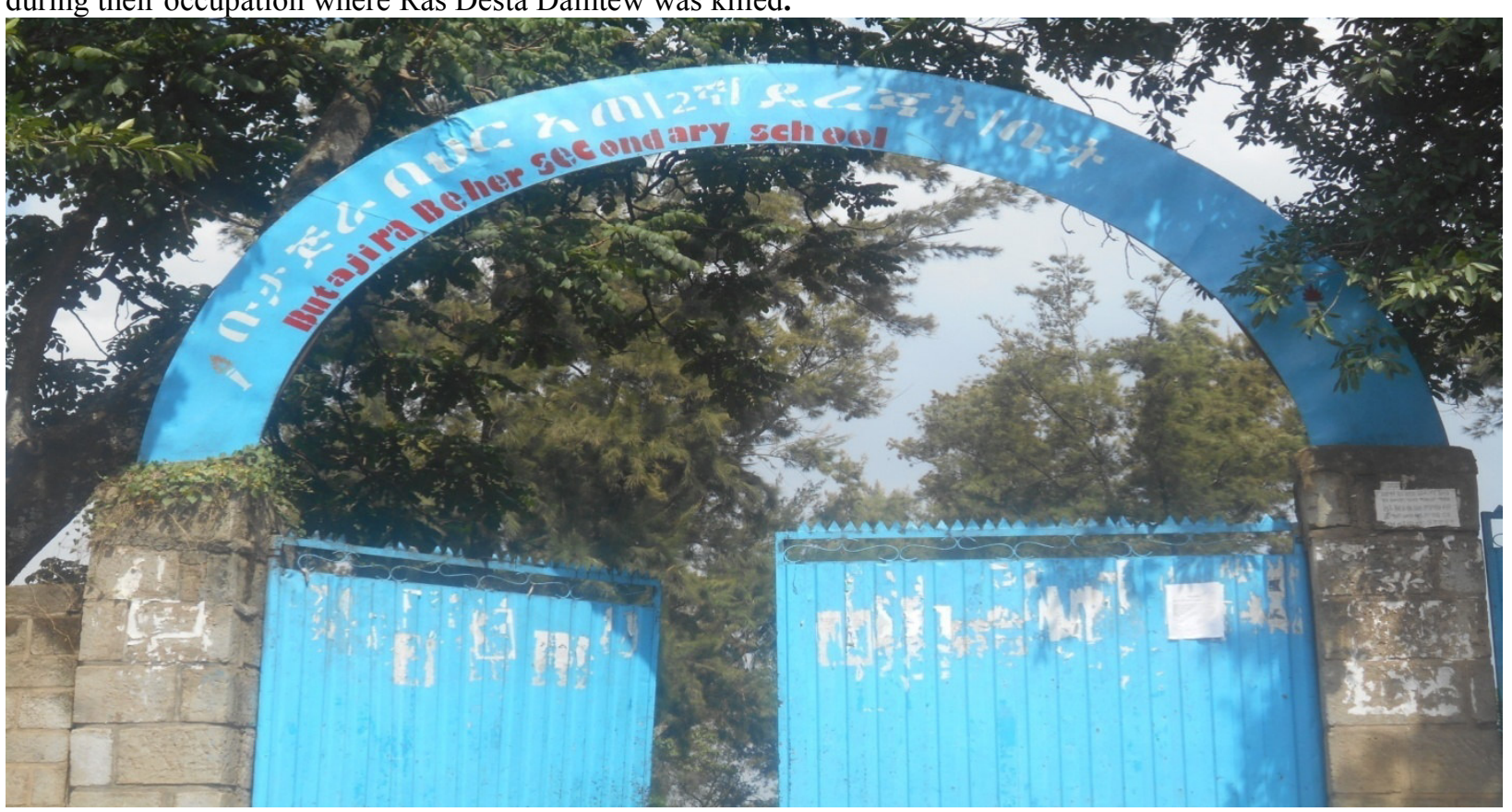

Photo by the researcher, May 25, 2020 
Photo 3

This picture shows the national flag in Butajira Behre General Secondary School it was the exact place where Ras Desta Damtew down after shoot by fascist shooting squad.

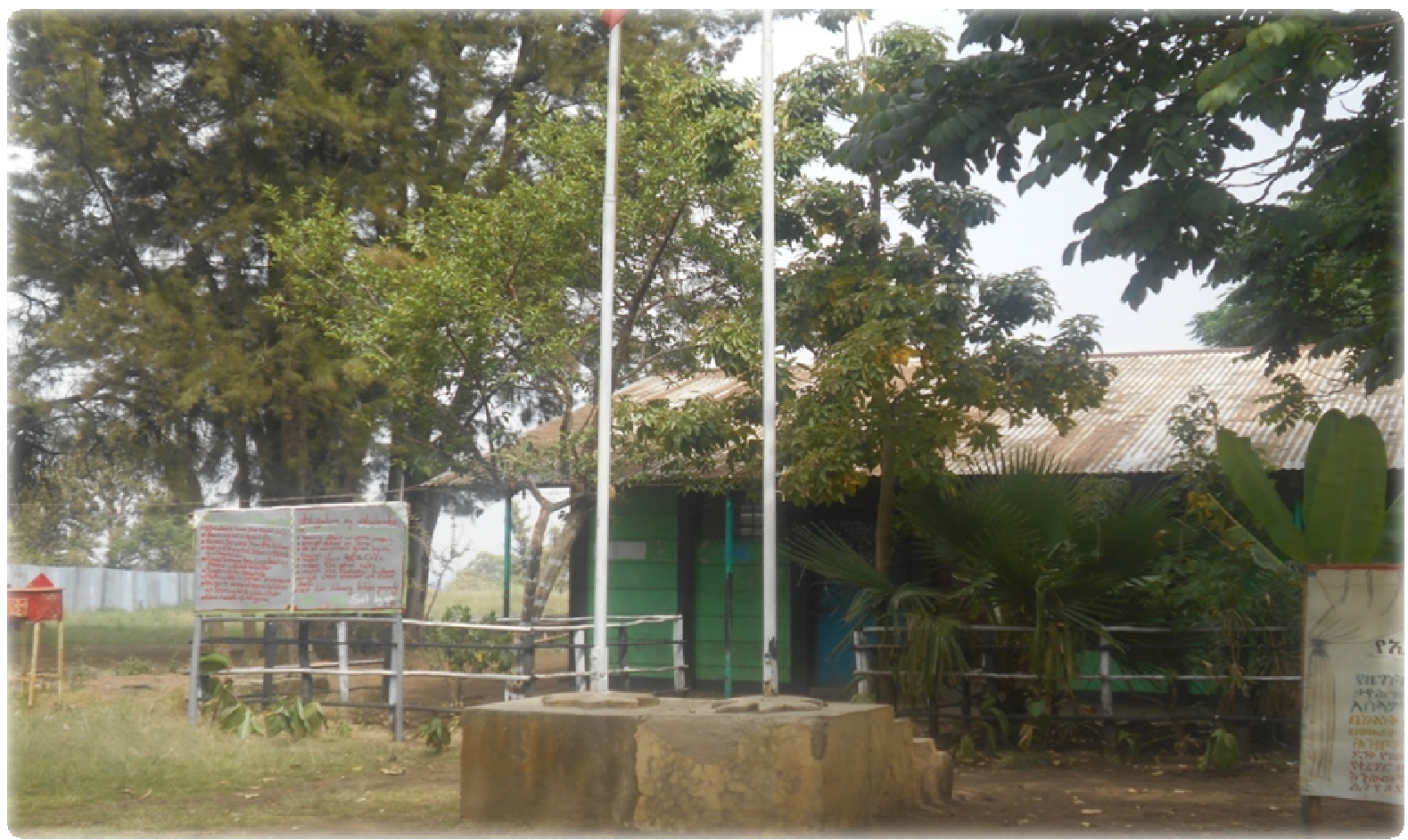

Photo by the researcher May 25, 2020

\section{Political and Economic Condition among the Mareko During The Italian Occupation: 1936-1941}

The victory of the Italians over the Ethiopians in the battles of Tembeyen, Maichew and Mekele brought about a political change in that the Ethiopian feudal government led by aristocrat Emperor Haile-Selassie was replaced by Italian rule. The event brought about the end of over four decades years-old gäbar-mälekn̆a relationship in Mareko like elsewhere in the country. This meant the end of the external obligations demanded by the mälekn̆a, such as tribute payment, both in kind and in cash: and the provision of labor services by the gäbar Mareko (Lapiso 1985; Informants: Ato Nune, and Abegaz Anbese). It is obvious there was the Italian change of policy, which eliminated tribute payment.

Like other areas of the country, in Mareko the feeling was dilemma mainly by ordinary people; appreciating the end of the aristocratic rule but hating the Italians rule. Conversely, part of the feudal class shows the opportunistic feeling to fit with the coming power and to maintain being elite. However to state the view of the majority ordinary class which was victim of the politically oppressive and economically exploitive feudal government, concerning the pro-Italian sentiment in the neighboring community Worku (2000) describes the following from the testimony of his informants;

"The Italians liberated the Gurage from näfţän̆a- caused slavery.

The näfţän̆a did not treat us equals, but as slave Because of their bad deeds Waa' took them to Maichew, where they were finished by the Italians. Waa' heard our cries and grievances and permitted the Maichew miracle to occur. Since then, there has been no payment [tribute], or work [free labor] for the näftän̆a, and we become free from them." (Worku 2000)

During the time of Italian occupation Mareko people who categorized under the administrative region of Mareko district in Dobenna sub-district represented by gerazmach Debo Agebo, governor of Mareko from Medore clan, ruling clan which recognized by emperor Menelik I. Italian administrative officials at their center at Butajira continued to rule Mareko people with collaborated gerazmach Debo (Informant; Imam Tuke, Ato Nune, and Abegaz Ambese Sintayhu 2002) particularly until they setup additional camp at Koshe, through strict supervision since submission changed in to collaboration.

Italians administrative officials at least weekly conduct their strict supervision in Dobenna meketele woreda (sub-district) at weekly market known as Oshebe-Mèra (Oshebe market) (Informants, Imam Tuke, Ato Nune, 
and Abegaz Ambese) The day had been intentionally selected to find more Mareko people than ordinary day then announce to all Mareko indigenous nobility, government officials most of them Amhara ethnic groups, religious representatives to arrive meet with local available Mareko people publicly concerning administrative issues. Under the pretext of "all blacks are equal..." (Tesfa 1995) Italian officials encouraged the ordinary class participants who emotionally insult higher class personalities if there is maladministration on the eye of fascist rule. Under such system Italian officials distort the former class relation and successfully made social antagonism among Mareko people.

The Italian occupation and administrative policy undertaken to facilitate the conquest which intentionally upload to stimulate interior disagreement and conflict, (Sbacchi 1985; Tesfa 1995; Marcus 1994) exacerbated an already occasionally erupt boundary conflict among ethnic and linguistic groups had have been living in Mareko district. Epicenter of the then border dispute was Mareko-land where Mareko people shared frontier with Mesakan-Gurage, Silte, and Sodo Gurage. Dispute occurred at the eve of Italian occupation when neighboring Silte group supported by Meskan Gurage invaded and war broke-out, which continued and serious of conflicts erupted until Italian occupation ended. Beside this Mareko people engaged in war against their northern neighbors, Sodo Gurage. These border conflicts and other wars which Mareko people fight against neighboring people were the result of Italian policy of "divide and rule"(Tesfa 1995).

Road construction marked the period of the Italian occupation, and the Mareko contributed significantly to the road-building Labor force. This role of the Mareko laborers in road construction has also been reported by the contemporary informants. Concerning the road construction by Italian government (Baker 1986) reported that, the construction of roads was one of the highest priorities for the Italians in their East African colonial agenda; and about 85 percent of their colonial budget was ear marked for road construction.

Baker (1986) also responded that the amount of roads the Italians constructed in Ethiopia added up to 7,000 kilometers, half of which were asphalted. Concerning this Baker stated that by 1941, the Italians had laid down an imposing road system throughout much of the country (Baker 1986). However Bahru (2002) explained the objective of Italian colonial road construction program and marked that "This is not surprising, as Italian roadbuilding was geared towards promoting the conquest of the country rather than its development."

Since Italians administration bases it's relatively fully functional at urban areas due to the activity of patriotic resistance movement in rural areas, Italian occupation in Mareko area first began to conduct road construction aimed at connecting Butajira with Ziway across Mareko-land to develop the accessibility of the area through infrastructure (Bahru 2002). This road construction project mainly used free labor corvee among Mareko youths since most part of the road crosses Mareko-land (Sintayhu 2002; Informants: Ato Hailu, Ato Lile, and Ato Demeke).

This forced work besides its exhaustiveness indirectly affects agricultural productivity in the area since most of Mareko-land farms had have been hold by family and clan base, in which elder men and other part of group excluded from plough and it had have been the duty of youth whom now become busy in forced road construction to whom it is new, long, and exhaustive (Informants: Ato Hailu, Ato Lile, and Ato Demeke). Consequently the project distorted the farming season which was contemporary which conducted by busy and exhausted recruits and then the season in which Mareko people depended on pass away with inefficiently ploughed and ill-harvest make feeding difficult.

Generally Italian occupation did not brought any significant economic change among Mareko people who depended on agriculture and animal husbandry. Even negatively affect production when they recruit youth, productive population among Mareko people for their road construction. Politically Italian rule can produce agents, collaborators from the nobility and appointed governor particularly after the resistance group lead by qän̆azmać Tuji Anjjilo exiled with his loyal followers.

\section{Conclusion}

The architects of Fascist aggression on Ethiopia were hopefully relied on the ethno-linguistic and religious heterogeneity of the people to apply their divide-rule policy to distort the unity and erase national sentiment of the people. However, the design checked its difficulty to apply in all areas and peoples after it failed to penetrate among the Mareko people.

The Mareko fighters combated the Italians at several national battle fields and back home after the unsuccessful battle of Maychew. The anti Fascist movement among the Mareko under taken into two methods, the first was led by the spiritual leader of the Mareko people named Wärèqè Märeyamè in which the majority of Mareko passively resist Fascist rule. The second was active resistance through armed force under the leadership of qän̆azmać Tuji Anjilo.

The active resistance of Mareko people forced the Fascist officials to establish camp in Koshe Kebele to easily control the movement. However, it was unsuccessful not only to get the submission of Mareko but also to weaken the resistance of patriots. Until the end of Fascist rule, the People of Mareko pay their life to the independence of their country, Ethiopia. 
Photo 4

An Italian artifact supposedly called rain gauge still stands in Koshe town in the compound of Mareko District Police Office which was the Italian camp during their occupation.

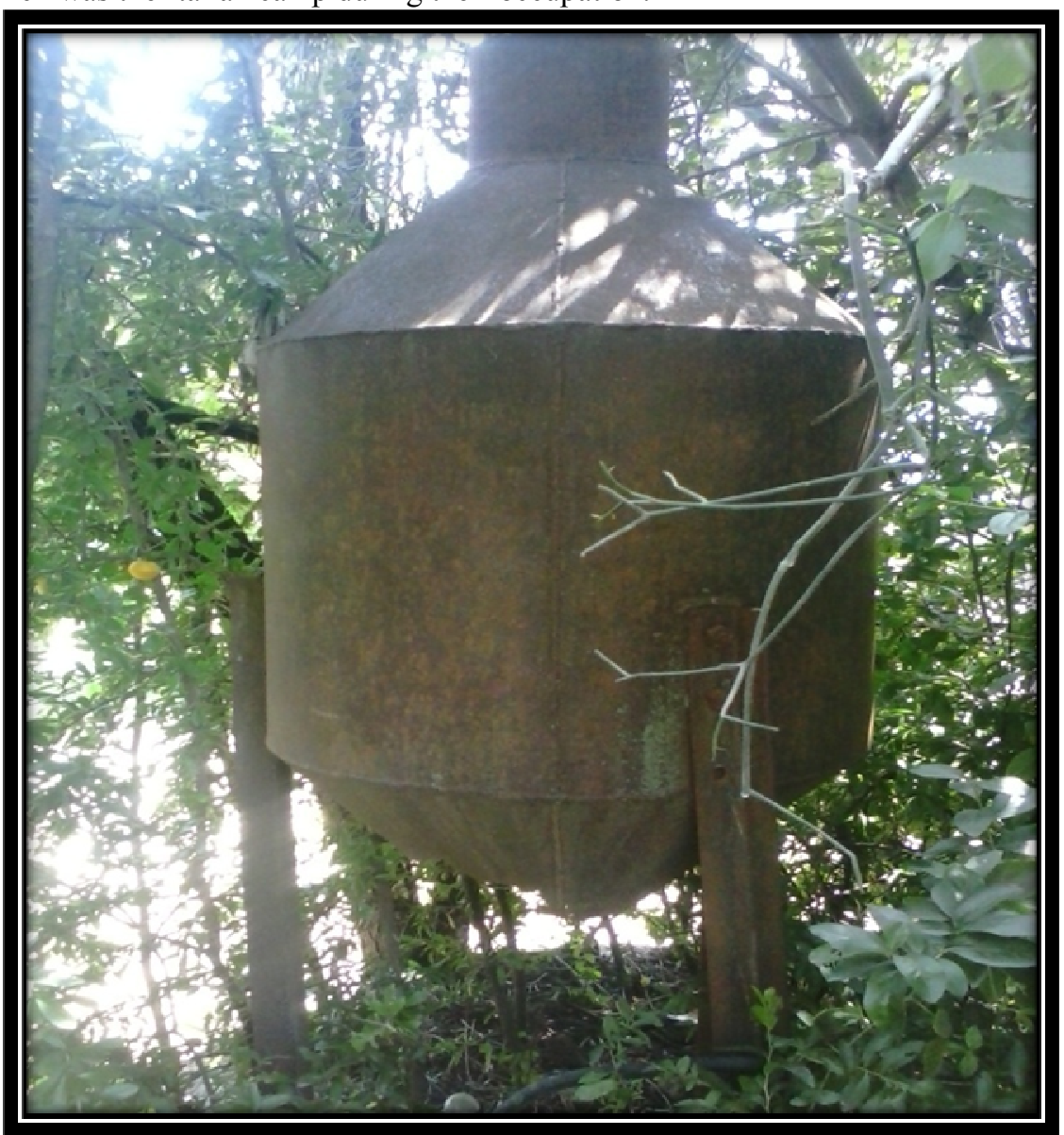

Photo by the researcher, May 25, 2020

\section{References}

Adejumobi, A. S., (2007), "The History of Ethiopia”, Westport, Connecticut, London.

Alebachew, K \& Samuel, H., (2010) "History and Culture of Hadiya People”. Addis Ababa, Sefir Printing.

Aregawi, B., (NP), "Sprit vs. War-machine: A Patriotic Resistance to Italian Occupation of Ethiopia (19361941)"

Bahru, Z. (2005), “A History of Modern Ethiopia 1855-1991”, Second Edition, Oxford, Athens, Addis Ababa.

Baker, J., (1986), "The Rural-Urban Dichotomy in the Developing World: A Case Study from Northern Ethiopia", London and New York: Norwegian University Press.

Behareseboch, M. (2004), "The profile of South Nation Nationalities and People's, Hawasa, Artistic Printing Agency, Ethiopia.

Bustorf, D. (2009), "Imam Sugato Zäyni, a War Lord of the Selt'e' Gogot" in: Proceedings of the $16^{\text {th }}$ International Conference of Ehiopian Studies, ed. By Svein Ege, Harald Aspen, Birhanu Teferra and Shiferaw Bekele, Trondheium, 151-161.

Daniel, M. Y., (2016), "Managing Inter-Ethnic Conflict through Indigenous Institutions-case of Siltie and Mareko Communities in Southern Ethiopia" International Peace and Conflict Studies, 3(1), 66-73.

Dergu G. (2006), "The Cause and Consequence of Population Migration from Rural to Urban in Koshe town”, BED Thesis, Department of Geography and Human Society, Dilla University, Dilla, Ethiopia.

Dinberu, A., Mengestu, H., Fikere, H., Tesfaye, M., Tezerach B., Girma, T., \& Miteku, T. (1995), “Gogot: History, Culture, and Language of the Gurage People" Department of Culture and Sport, Artistic Printers Press.

Edemo, H. (1998), "Metē: the Culture and History of Libido/Mareko People" Paper Presented on Panel Discussion, Koshe, Ethiopia.

Haile-Selassie, (1936), "My Life and Ethiopia's’ Progress", England, Bath.

Lapiso, D. (1985), “Ye Ethiopia Ye Mekera Siratena Eritera”, (Amharic), Addis Ababa. 
Marcus, H. (1994), “A History of Ethiopia”, University of California Press, Berkeley, Los Angeles, London.

Sbacchi, A. (1974), "Secret Talks for the Submission of Haile Selassie and Prince Asfaw Wessen 1936-1939" International Journal of African Historical Studies, 7(4), 668-680.

Sbacchi, A. (1977), "Italy and the treatment of Ethiopian Aristocracy, 1937-1940" the International Journal of African Historical Studies, 10(2), 209-241.

Sbacchi, A. (1985), "Ethiopia under Mussolini", Bath Press.

Sintayhu, W. (2002) “A Socio Political and Economic History of Mareko People: 1936-1974” BA Thesis, Department of History Dire Dawa University, Ethiopia.

Teclehaimanot, G. (2014), "The Low-Caste Fuga Occupational Group under the Italian Administration in the Horn of Africa" Northeast Africa Studies, The Horn of Africa between History, Law, and Politics, Michigan State University Press New Series, 10(3), 33-44.

Tesfa, G. (1995), “Aymalale: a History of Gurage of Sodo-Gordena” Ed, Worku T., Addis Ababa.

Vaughan S. (2003), "Ethnicity and Power in Ethiopia", University of Edinburgh.

Worku, N. (2000) "Fanonet: Ethnohistorical Notes on the Gurage Urban Migration in Ethiopia", Ufahamu: $A$ Journal of African Studies, 28(2-3), 43-71. 